\title{
Effect of seminal plasma or transforming growth factor on bovine endometrial cells
}

\author{
Jason A Rizo ${ }^{1}$, Laila A Ibrahim, Paula C C Molinari ${ }^{1}$, Bo R Harstine ${ }^{2}$, Rachel L Piersanti ${ }^{1}$ and \\ John J Bromfield ${ }^{1}$ \\ ${ }^{1}$ Department of Animal Sciences, University of Florida, Gainesville, Florida, USA and ${ }^{2}$ Select Sires Inc., Plain City, \\ Ohio, USA \\ Correspondence should be addressed to J J Bromfield; Email: jbromfield@ufl.edu
}

\begin{abstract}
Semen induces post-coital inflammation of the endometrium in several species. Post-coital inflammation is proposed to alter the endometrial environment of early pregnancy, mediate embryonic development and modulate the maternal immune response to pregnancy. In cattle, it is common for pregnancies to occur in the absence of whole semen due to the high utilization of artificial insemination. Here, we have utilized a cell culture system to characterize semen-induced expression of inflammatory mediators in bovine endometrial cells and test the efficacy of transforming growth factor beta as the active agent in mediating any such change. We hypothesize that seminal plasma-derived transforming growth factor beta increases the expression of inflammatory mediators in bovine endometrial cells. Initially, we describe a heat-labile cytotoxic effect of seminal plasma on BEND cells, and a moderate increase in IL1B and IL6 expression. In addition, we show that transforming growth factor beta is present in bovine semen and can increase the expression of endometrial IL6, whereas blocking transforming growth factor beta in semen ameliorates this effect. However, intra-uterine infusion of seminal plasma, sperm or transforming growth factor beta did not alter the endometrial expression of inflammatory mediators. We conclude that bovine semen can modulate endometrial gene expression in vitro, which is partially due to the presence of transforming growth factor beta. It is likely that additional, unidentified, bioactive molecules in semen can alter the endometrial environment. Characterizing bioactive molecules in bovine semen may lead to the development of additives to improve artificial insemination in domestic species.
\end{abstract}

Reproduction (2019) 158 529-541

\section{Introduction}

Studies in mice, swine and humans have demonstrated that seminal plasma mediates a post-coital inflammatory response in female reproductive tissues which modulate the maternal response to pregnancy (Yanagimachi \& Chang 1963, Robertson \& Seamark 1992, O'Leary et al. 2004, Sharkey et al. 2012b). More recently, in vitro studies have confirmed a similar response in bovine endometrium (Ibrahim et al. 2019). The periconceptional period of pregnancy is a critical window of development than can influence embryo survival and affect the longterm health of offspring (Louis et al. 2008). In mice, pregnancies established in the absence of seminal plasma result in male offspring with altered metabolic phenotypes (Bromfield et al. 2014), suggesting that postcoital inflammation has long-term effects on pregnancy and offspring health.

Seminal plasma-derived transforming growth factorbeta (TGF $\beta$ ) has been identified as a major component of semen to elicit the post-coital inflammatory response in female reproductive tissues of mice and humans (Tremellen et al. 1998, Robertson 2005), and its concentration in bovine seminal plasma is currently unknown. The endometrial inflammatory response to seminal plasma has been characterized in numerous species by increased expression of CSF2, IL1B, IL6, TNF, PTGS2, LIF and IL17A (Gutsche et al. 2003, O'Leary et al. 2004, Robertson et al. 2015). Many of these specific cytokines have the capacity to influence maternal immune cell populations during pregnancy (Chen et al. 2003, Ghiringhelli et al. 2005, Fridlender et al. 2009), in addition to acting as embryokines to support preimplantation embryo development (Hansen et al. 2014, Tribulo et al. 2018).

The success of assisted reproductive techniques including ICSI, IVF and artificial insemination affirms that seminal plasma is not essential for the establishment of pregnancy. Indeed, pregnancy rates using artificial insemination in cattle are similar to natural service (Lima et al. 2009), and generally pregnancy rates achieved by embryo transfer are higher than those for artificial insemination (Pellegrino et al. 2016). However, cows undergoing artificial insemination using diluted/ extended semen are not exposed to physiological 
components of the ejaculate. Hence, the response of the endometrium to semen is not well studied in cattle, while any influence of seminal plasma on bovine fertility is yet to be established. However, intrauterine infusion of TGF $\beta-1$ at the time of artificial insemination increased pregnancy rates in cattle with low fertility (Odhiambo et al. 2009), while seminal plasma supplementation at the time of artificial insemination increased birth weight of heifer calves (Ortiz et al. 2019). In dairy cattle, the highest incidence of pregnancy loss occurs in the first week of pregnancy when approximately $40 \%$ of embryos fail to develop further than the blastocyst stage (Santos et al. 2004, Wiltbank et al. 2016). Therefore, this window of development is a critical target for modulating the maternal environment in order to increase pregnancy success in the cow. Previously, we have demonstrated that seminal plasma modulates the expression of inflammatory mediators in bovine ex vivo-cultured endometrial explants and semi-purified, primary endometrial cells (Ibrahim et al. 2019).

Here, we utilized in vitro culture of the bovine endometrial (BEND) cells and intrauterine infusion to evaluate cell viability and expression of cytokines and embryokines in response to semen components, including TGF $\beta$. In addition, we have quantified the TGF $\beta$ content of bull semen. We hypothesize that seminal plasma or TGF $\beta$ increases the expression of cytokines and embryokines in endometrial cells under the influence of estradiol. The utility of the BEND cell line here could be used as a tool for future testing of paternal factors that may modulate endometrial function. The identification of semen components that could improve bovine reproduction and reduce economic losses associated with pregnancy failure may help to optimize artificial insemination in domestic species.

\section{Materials and methods}

\section{Chemicals and reagents}

All reagents were acquired from Fisher Scientific unless otherwise specified.

\section{Seminal plasma collection}

Whole semen was collected from healthy Angus bulls by electroejaculation during two separate breeding soundness evaluations (BSE) at the University of Florida North Florida Research and Extension Center. Whole semen from 21 bulls was collected on the first BSE and from 12 bulls were collected during the second BSE. Sample contamination was minimized as best could be achieved in field conditions. Whole semen was evaluated and further processed only if free of blood, urine and other visual abnormalities. Parameters recorded during the BSE included bull ID, collection date, ejaculated volume, scrotal circumference, and sperm motility, morphology and concentration. On average, whole semen volume ranged from 4 to $15 \mathrm{~mL}$, gross motility ranged from 10 to $90 \%$, and scrotal circumference ranged from 31 to $49 \mathrm{~cm}$. Following semen collection, samples were placed on ice and transported to the laboratory for processing under aseptic conditions. Ejaculates were centrifuged at $12,000 \mathrm{~g}$ for $20 \mathrm{~min}$ at $4^{\circ} \mathrm{C}$ to separate seminal plasma from the cellular fraction of the ejaculate. Cell free seminal plasma was placed in sterile tubes in aliquots of 500 to $1000 \mu \mathrm{L}$ and stored at $-20^{\circ} \mathrm{C}$ until use.

\section{Preparation of pooled seminal plasma}

Seminal plasma ( 1 or $2 \mathrm{~mL}$ ) from 21 individual bulls, collected during the first BSE, was combined to prepare a seminal plasma pool. Pooled seminal plasma was either immediately stored at $-20^{\circ} \mathrm{C}$ in $500 \mu \mathrm{L}$ aliquots or filtered through a 0.22 $\mu \mathrm{m}$ filter prior to storage. In addition, thawed seminal plasma was also heat-treated at $90^{\circ} \mathrm{C}$ for $10 \mathrm{~min}$ prior application to cells. A second pool of seminal plasma was generated with ejaculates from 12 individual bulls of the second BSE.

\section{Quantification of TGF in bull seminal plasma}

Currently, there are no commercially available bovine-specific TGF $\beta$ ELISA kits and therefore a human TGF $\beta-1$ and TGF $\beta-2$ ELISA were used according to the manufacturer's instructions (Human TFG $\beta-1$ DuoSet, and Human TFG $\beta-2$ DuoSet; R\&D Systems). The concentrations of bioactive TGF $\beta-1$ and TGF $\beta-2$ were determined in untreated seminal plasma, while quantification of total TGF $\beta-1$ and TGF $\beta-2$ required acid activation of seminal plasma. For acid activation, $100 \mu \mathrm{L}$ of seminal plasma was first diluted in $300 \mu \mathrm{L}$ of Dulbecco's phosphate buffered saline (DPBS) before the addition of 50 $\mu \mathrm{L}$ of $1 \mathrm{M} \mathrm{HCl}$. Samples were incubated for $20 \mathrm{~min}$ at room temperature before neutralizing the $\mathrm{pH}$ with the addition of $50 \mu \mathrm{L}$ of $1 \mathrm{M} \mathrm{NaOH}$. Quantification of total TGF $\beta-1$ and total TGF $\beta-2$ was evaluated at 1:300 and 1:600, and 1:5 and $1: 10$ final dilutions respectively. Quantification of bioactive TGF $\beta-1$ and TGF $\beta$-2 were evaluated neat and at 1:5 and $1: 10$, respectively. The limit of detection for both TGF $\beta-1$ and TGF $\beta$-2 was $31.3 \mathrm{pg} / \mathrm{mL}$. Both TGF $\beta-1$ and TGF $\beta-2$ ELISAs were validated using spike-in/recovery performance efficiency based on actual and expected recovery of recombinant TGF $\beta$ in each ELISA kit. The rate of recovery for TGF $\beta-1$ was $82-97 \%$ and TGF $\beta$ - 2 was $75-108 \%$.

\section{Reconstitution of rhTGF $\beta-1, r h T G F \beta-2$ and TGF $\beta$ pan specific antibody}

A total of $10 \mu \mathrm{g}$ of recombinant human transforming growth factor beta 1 (rhTGF $\beta$-1) (240-B; R\&D System) was reconstituted in $500 \mu \mathrm{L}$ of sterile $4 \mathrm{mM} \mathrm{HCl}$ containing $1 \mathrm{mg} / \mathrm{mL}$ BSA fraction $V$ in DPBS to achieve a $20 \mu \mathrm{g} / \mathrm{mL}$ stock solution. Stock solutions were diluted 1:20 in sterile DPBS containing $25 \mu \mathrm{g} /$ $\mathrm{mL}$ of gentamicin to achieve a working stock concentration of $1 \mu \mathrm{g} / \mathrm{mL}$ rhTGF $\beta-1$. Working stock solutions were stored in 40 $\mu \mathrm{L}$ aliquots at $-80^{\circ} \mathrm{C}$.

A total of $5 \mu \mathrm{g}$ of recombinant human transforming growth factor beta 2 (rhTGF $\beta$-2) (302-B2; R\&D System) was reconstituted in $50 \mu \mathrm{L}$ of molecular grade water to achieve a $0.1 \mathrm{mg} / \mathrm{mL}$ stock solution. Stock solutions were diluted 1:100 
in sterile DPBS containing $1 \mathrm{mg} / \mathrm{mL}$ BSA to achieve a working stock concentration of $1 \mu \mathrm{g} / \mathrm{mL}$ rhTGF $\beta-2$. Working stock solutions were stored in $40 \mu \mathrm{L}$ aliquots at $-80^{\circ} \mathrm{C}$.

A total of $1 \mathrm{mg}$ of transforming growth factor beta pan specific antibody ( $\alpha$ TGF $\beta$ ) (AB-100-NA; R\&D System) was reconstituted in $1 \mathrm{~mL}$ of sterile DPBS to achieve a $1 \mathrm{mg} / \mathrm{mL}$ stock solution. Working stock solutions were stored in $50 \mu \mathrm{L}$ aliquots at $-80^{\circ} \mathrm{C}$. Prior to treatment, working stock solutions were diluted 1:20 in complete culture medium to achieve a concentration of $50 \mu \mathrm{g} / \mathrm{mL}$ of $\alpha \mathrm{TGF} \beta$.

\section{Culture of bovine endometrial (BEND) cells}

Bovine endometrial epithelial (BEND) cells (Johnson et al. 1999) were purchased from American Type Culture Collection (ATCC) and cultured according to the distributor's instructions. Briefly, BEND cells were cultured to $85 \%$ sub confluence in 75 $\mathrm{cm}^{2}$ flasks (Greiner Bio-One, Frickenhausen, Germany) in a 1:1 mixture of Dulbecco's Minimum Essential Medium (DMEM) and Ham's F12 Nutrient Mixture Medium supplemented with 1.5 g/L sodium bicarbonate, $0.034 \mathrm{~g} / \mathrm{L}$ D-valine, $10 \%$ fetal bovine serum (FBS), and $10 \%$ horse serum. Cultures were maintained at $38.5^{\circ} \mathrm{C}$ in a humidified $5 \% \mathrm{CO}_{2}$ environment. Complete culture medium was equilibrated to incubator conditions and changed every $48 \mathrm{~h}$ until cells reached sub confluence. Prior to treatment, cells were detached from flasks using $0.25 \%$ trypsin with $0.1 \%$ EDTA, washed in warm DPBS by centrifugation and resuspended in equilibrated culture medium. Cells were plated at a final concentration of $10^{5}$ cells $/ \mathrm{mL}$ in 24 - or 96 -well culture plates (TPP, Trasadingen, Switzerland). Cultures were equilibrated for $24 \mathrm{~h}$ to facilitate cellular attachment before the addition of treatments (described below).

\section{Isolation and culture of primary bovine endometrial epithelial and stromal cells}

Uteri from post pubertal, non-pregnant cows were collected at a local slaughterhouse and processed at room temperature (RT) within $4 \mathrm{~h}$ of collection. Whole reproductive tracts were collected if no overt signs of infection were observed. A total of six reproductive tracts at stage 3 (day 11-17 of the estrous cycle) were used for all cultures. The stage of the estrous cycle was classified based on corpus luteum characteristics including internal and external appearance, diameter, surface vasculature, and presence of the corpus luteum as previously reported (Ireland et al. 1980).

Epithelial and stromal cells were isolated and cultured as previously described (Cronin et al. 2012). Briefly, external surfaces of the uteri were disinfected with $70 \%$ ethanol and the ipsilateral horn to the corpus luteum was opened with a transverse cut into the center of the horn, above the intercornual ligament and longitudinal to the ovary. The exposed endometrium was washed twice with DBPS supplemented with $50 \mathrm{IU} / \mathrm{mL}$ penicillin, $50 \mu \mathrm{g} / \mathrm{mL}$ streptomycin and $2.5 \mu \mathrm{g} / \mathrm{mL}$ amphotericin B to remove mucus and potential microorganisms. Endometrial tissue from intercaruncular regions was dissected into thin strips and placed into Hank's balanced salt solution (HBSS) supplemented with $50 \mathrm{IU} / \mathrm{mL}$ penicillin, $50 \mu \mathrm{g} / \mathrm{mL}$ streptomycin and $250 \mu \mathrm{g} / \mathrm{mL}$ amphotericin B. Endometrial tissue was further dissected into 3-5 $\mathrm{mm}^{2}$ pieces and transferred into warm HBSS and maintained at $37^{\circ} \mathrm{C}$ for $10 \mathrm{~min}$. Enzymatic digestion was achieved in HBSS supplemented with 100 mg BSA, 125 CDU/ mg collagenase II (Sigma-Aldrich), 250 BAEE trypsin (SigmaAldrich), and $4 \%$ DNase I at $37^{\circ} \mathrm{C}$ with shaking for $1 \mathrm{~h}$. Resultant cell suspension was then filtered through a $40 \mu \mathrm{m}$ filter into warm HBSS supplemented with $10 \%$ FBS to stop enzymatic activity. The filtered suspension was centrifuged at $500 \mathrm{~g}$ for $7 \mathrm{~min}$ at RT and the endometrial cell pellet was resuspended in $5 \mathrm{~mL}$ of complete culture medium (RPMI 1640 medium supplemented with $10 \%$ FBS, 2 mM of L-glutamine, $50 \mathrm{IU} / \mathrm{mL}$ penicillin, $50 \mu \mathrm{g} / \mathrm{mL}$ streptomycin, and $2.5 \mu \mathrm{g} / \mathrm{mL}$ amphotericin B) equilibrated to $38.5^{\circ} \mathrm{C}$. Cells were transferred to $75 \mathrm{~cm}^{2}$ flasks (Greiner Bio-One) containing $25 \mathrm{~mL}$ of equilibrated culture medium and maintained at $38.5^{\circ} \mathrm{C}$ in a humidified $5 \% \mathrm{CO}_{2}$ environment. Following $18 \mathrm{~h}$ of culture, epithelial cells in suspension were transferred to a new flask while adherent stromal cells remained in the original culture flask. After a total of $66 \mathrm{~h}$ in culture, cells were detached from flasks using HyQTase, washed with warm DPBS, resuspended at a final concentration of $10^{5}$ cells $/ \mathrm{mL}$ and plated in $500 \mu \mathrm{L}$ of culture medium in 24-well culture plates for $24 \mathrm{~h}$ prior to treatment. Purity of epithelial and stromal cells was assessed using flow cytometry and previously reported to be $56 \pm 16 \%$ and $95 \pm 3 \%$, respectively (Ibrahim et al. 2019).

\section{Treatment of primary and BEND cell cultures}

All treatments were added to complete culture medium prior to the application to either BEND cells or primary endometrial cells. Treatments included medium alone as a negative control, seminal plasma $(0.001 \%, 0.01 \%, 0.1 \%, 1 \%, 5 \%, 10 \%$, or $20 \% \mathrm{v} / \mathrm{v})$, rhTGF $\beta-1$ (1 ng, $10 \mathrm{ng}$ or $100 \mathrm{ng} / \mathrm{mL}$ ), rhTGF $\beta-2$ $(0.1 \mathrm{ng}, 1 \mathrm{ng}$ or $10 \mathrm{ng} / \mathrm{mL})$, or neutralizing pan-TGF $\beta$ antibody ( $1 \mu \mathrm{g}, 5 \mu \mathrm{g}, 10 \mu \mathrm{g}$, or $20 \mu \mathrm{g} / \mathrm{mL}$ ). Seminal plasma was preincubated with neutralizing pan-TGF $\beta$ antibody for 5 min prior to application to cells. $17 \beta$-estradiol was supplemented to culture medium at a final concentration of $0,0.1$ or $1 \mathrm{nM}$. Cells were exposed to treatments for $0,1,3,6,12$ or $24 \mathrm{~h}$. Experiments using BEND cells were repeated at least four times and each replicate represents cells between passages 1 and 11. Experiments using primary cells were replicated six times, with each replicate being representative of endometrial cells from an individual cow. Following treatment, cells were washed with warm DPBS and stored in $350 \mu \mathrm{L}$ of RLT Lysis Buffer (Qiagen) at $-80^{\circ} \mathrm{C}$ to facilitate extraction of total RNA.

\section{Evaluation of endometrial cell viability}

Viability of BEND cells was assessed by colorimetric analysis using the MTT assay (Mosmann 1983). Cells were plated at $10^{5}$ cells $/ \mathrm{mL}$ in 96-well culture plates (TPP) in a final volume of $200 \mu \mathrm{L}$ of cell culture medium and equilibrated for $24 \mathrm{~h}$ prior to treatment. Treatments (above) were applied to cells in duplicate for $24 \mathrm{~h}$ and assays were repeated at least four times. Following treatment, $10 \mu \mathrm{L}$ of $5 \mathrm{mg} / \mathrm{mL}$ MTT was added to each well and incubated for $2 \mathrm{~h}$ prior to washing in warm DPBS. Cellular formazan was solubilized in $100 \mu \mathrm{L}$ of 
DMSO per well and incubated for $15 \mathrm{~min}$ at RT in the dark. Optical density of each well was measured at $540 \mathrm{~nm}$ using a microplate reader (BioTek, Winooski, VT, USA) and the blank corrected value for each treatment was calculated using the average of the duplicate wells. Data were normalized as fold change from the medium alone treated cells.

\section{Estrus synchronization, intrauterine infusion and endometrial sampling}

All animal use was approved and conducted in accordance to University of Florida Institutional Animal Care and Use Committee. Cows received $100 \mathrm{mg}$ of $\mathrm{GnRH}$ (gonadorelin diacetate tetrahydrate; Ovacyst, Bayer Animal Health, Whippany, NJ, USA) i.m., followed 7 days later by $25 \mathrm{mg}$ i.m. of prostaglandin F2 $\alpha$ (dinoprost tromethamine; Prostamate, Bayer). Behavioral estrous was determined by activation of an estrus detection patch (ESTROTEC Breeding Indicator) applied at the time of prostaglandin administration. Intrauterine treatments were applied to cows $12 \mathrm{~h}$ following detection of behavioral estrus.

Treatments consisted of intrauterine infusion of either saline $(0.9 \% \mathrm{NaCl} ; n=5)$, washed sperm $(n=5)$, pooled seminal plasma $(n=5)$ or 10 ng rhTGF $\beta-1(n=5)$ applied using semen straws and artificial insemination technique. Sterile saline solution including $20 \mu \mathrm{L} / \mathrm{mL}$ antibiotic (Antibiotic Supplement for Neat Semen and CSS Extenders, Minitube, USA) was used as vehicle for all treatments. Pooled seminal plasma was packaged in $0.5 \mathrm{~mL}$ straws by Select Sires Inc. (Plain City, $\mathrm{OH}$, USA) as previously described (Ortiz et al. 2019). Frozen, extended semen was thawed at $36.5^{\circ} \mathrm{C}$ for $30 \mathrm{~s}$ and centrifuged at $500 \mathrm{~g}$ for $5 \mathrm{~min}$. The supernatant was discarded and washed sperm was resuspended in $0.5 \mathrm{~mL}$ vehicle solution and loaded into a single $0.5 \mathrm{~mL}$ straw for immediate intrauterine infusion. Semen from a single bull was used throughout the experiment. All treatments were infused into the uterine body by standard artificial insemination technique (Ibrahim et al. 2019).

Endometrial cytobrush samples were collected $12 \mathrm{~h}$ after intrauterine infusion of treatments as previously described (Cardoso et al. 2017). Briefly, external genitalia were cleaned with $70 \%$ ethanol and the cytobrush tool (Medscand Medical, Cooper Surgical, Trumbull, CT, USA) which was held inside a metal sheath covered by a plastic chemise was introduced into the vagina and passed through the cervix by rectal palpation. The plastic chemise was retracted over the tool and the cytobrush was exposed to the endometrium and rotated three times to collect endometrial cells. Upon retraction, the cytobrush was snap frozen in liquid nitrogen and stored at $-80^{\circ} \mathrm{C}$. Total RNA was extracted from cytobrush samples using the TRIzol (Life Technologies, Carlsbad, CA, USA) method before processing for PCR (below).

\section{Extraction of cellular RNA and qPCR}

Total RNA was extracted from cultured cells using the RNeasy Mini Kit according to manufacturer's instructions (Qiagen).

Extracted RNA was resuspended in $30 \mu \mathrm{L}$ of RNAasefree water and quantified using a NanoDrop ND1000 spectrophotometer. A total of $1 \mu \mathrm{g}$ of RNA was subjected to RT using the Verso cDNA synthesis kit according to manufacturer's instructions including a genomic DNA wipe out step. Resultant cDNA was diluted 1:3 in molecular grade water and stored at $-80^{\circ} \mathrm{C}$.

Primers used for real-time RT-PCR were designed using the $\mathrm{NCBI}$ database and verified by BLAST. Primer details are listed in Table 1. Amplification efficiency was evaluated for each primer by performing serial dilutions of cDNA to confirm linear amplification and confirmed by visualization of PCR product on a $1 \%$ agarose gel. All primers met MIQE guidelines for use (Pearson correlation coefficient $r^{2}>0.98$ and efficiency between 90 and $110 \%$ ). Real-time RT-PCR was performed in $20 \mu \mathrm{L}$ reactions using iTaq Universal SYBR green chemistry (Bio-Rad) with $100 \mathrm{nM}$ of each forward and reverse primer. A Bio-Rad CFX Connect light cycler (Bio-Rad) was employed to perform PCR using a two-step protocol with the following recommended thermal cycling conditions: initial denaturation/ enzyme activation at $95^{\circ} \mathrm{C}$ for $30 \mathrm{~s}$, followed by 40 cycles of denaturation at $95^{\circ} \mathrm{C}$ for $5 \mathrm{~s}$, and annealing/extension for 30 $\mathrm{s}$ at $60^{\circ} \mathrm{C}$. Samples were analyzed in duplicate and each PCR reaction was followed by melt curve analysis to ensure single product amplification. A no template negative control was used in place of cDNA to determine non-specific amplification. Expression data for genes of interest were normalized to GAPDH and expressed using the $2^{-\Delta \mathrm{Ct}}$ method.

\section{Statistical analysis}

Data were analyzed using SPSS software V24.0 (IBM Analytics, Armonk, NY, USA). Data were assessed with Shapiro-Wilk test and log transformed when appropriate (described in figure legends). Data were analyzed using the generalized linear mixed model with dose, treatment and time as fixed factors. Pairwise comparisons were performed between each dose and vehicle controls. Statistical significance was declared when $P \leq 0.05$.

\section{Results}

\section{The effect of seminal plasma on BEND cell viability}

Viability of BEND cells was assessed after $24 \mathrm{~h}$ exposure with medium alone or $0.001,0.01,0.1,1,5,10$, or $20 \%$ $(\mathrm{v} / \mathrm{v})$ seminal plasma (Fig. 1). To assess the cytotoxic effects of seminal plasma, pooled seminal plasma from the first BSE of 21 bulls was used. Viability of BEND cells was approximately $14 \%$ following exposure to $1 \%$ seminal plasma compared to medium alone $(P \leq 0.05)$, whereas viability was $<2 \%$ following exposure to 5,10 or $20 \%$ seminal plasma (Fig. $1 \mathrm{~A}, P<0.05$ ). To determine the nature of the cytotoxic component of seminal plasma, treatments were either filtered, heat-treated or filtered and then heat-treated prior to exposure of cells. Filtering seminal plasma had no effect on seminal plasma cytotoxicity (Fig. 1B), whereas heat treatment reduced the cytotoxic effects of seminal plasma so that only 10 and $20 \%$ exposure resulted in cell death (Fig. 1C, $P<0.05)$. The combination of filtering and heat treatment of seminal plasma resulted in cytotoxicity 
Table 1 List of qPCR primer sequences for target gene analysis.

\begin{tabular}{|c|c|c|c|c|}
\hline \multirow[b]{2}{*}{ Gene } & \multicolumn{2}{|c|}{ Primer sequence $\left(5^{\prime}-3^{\prime}\right)$} & \multirow[b]{2}{*}{ GenBank accession number } & \multirow[b]{2}{*}{ Product size $(b p$} \\
\hline & Forward & Reverse & & \\
\hline CSF2 & TTCCTGTGGAACCCAGTTTATC & TTTGGCСTGCTTCACTTCT & NM_174027.2 & 114 \\
\hline GAPDH & AGGTCGGAGTGAACGGATTC & ATGGCGACGATGTCCACTTT & NM_001034034.2 & 114 \\
\hline IL1B & CTTCATTGCCCAGGTTTCTG & CAGGTGTTGGATGCAGCTCT & NM_174093.1 & 142 \\
\hline IL6 & АTGАСТTСТGСТTTСССТАССС & GСТGСТTTCАСАСТСАТСАТTC & XM_015468553.1 & 180 \\
\hline TNF & CACATACССТGCCACAAGGC & СTGGGGACTGСTСТTСССТСТ & NM_173966.3 & 261 \\
\hline
\end{tabular}

effects following exposure to 10 or $20 \%$ seminal plasma (Fig. 1D, $P<0.05$ ). Seminal plasma was not toxic to BEND cells at concentrations between 0.001 and $0.1 \%$.

\section{The effect of seminal plasma on BEND cell gene expression}

The capacity for seminal plasma to modulate BEND cell expression of CSF2, IL1B, IL6 and TNF was evaluated following 24-h exposure to $0.001,0.01,0.1$, or $1 \% \mathrm{v} / \mathrm{v}$ seminal plasma or medium alone (Fig. 2). Seminal plasma from the first BSE of 21 bulls was either non-treated, filtered, heat-treated, or filtered and then heat-treated.

Expression of CSF2 (Fig. 2A) was unaffected following exposure to non-treated or filtered seminal plasma, whereas exposure to 0.1 or $1 \%(\mathrm{v} / \mathrm{v})$ heat-treated or filtered and heat-treated seminal plasma reduced CSF2 expression compared to medium alone treated cells $(P \leq 0.05)$. Expression of IL1B (Fig. 2B) was reduced following exposure to all seminal plasma treatment conditions compared to medium alone treated cells $(P \leq 0.05)$. Expression of IL6 (Fig. 2C) was increased following exposure to all seminal plasma treatment
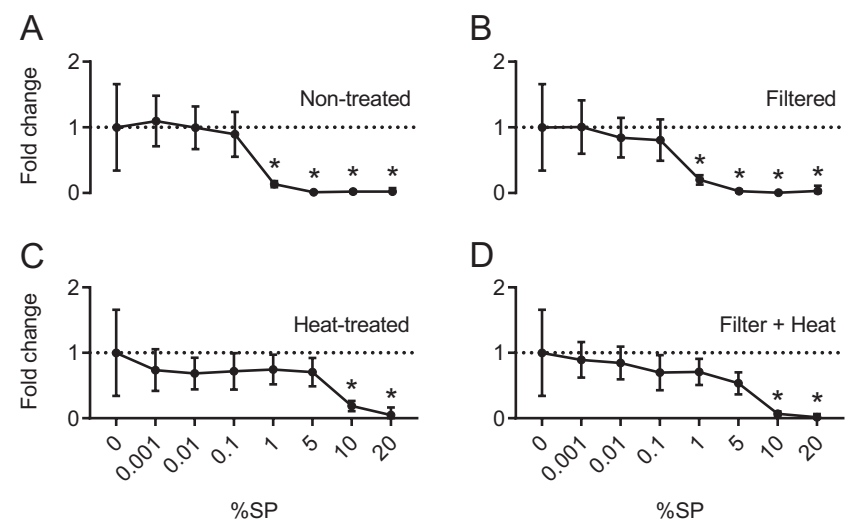

Figure 1 Effect of seminal plasma on BEND cell viability. Cell viability was assessed using the MTT assay after 24-h treatment with medium alone $(0)$ or $0.001,0.01,0.1,1,5,10$, or $20 \% \mathrm{v} / \mathrm{v}$ seminal plasma (SP). Seminal plasma was either non-treated (A), filtered (B), heat-treated $(C)$ or both filtered and heat-treated (D). Data are presented as mean fold-change of medium alone treated cells \pm S.E.M. Experiments were replicated in at least eight independent assays.

Data were log transformed and analyzed using the generalized linear mixed model and pairwise comparisons were made between medium alone and each seminal plasma concentration. *, represents $P \leq 0.05$ compared to medium alone. conditions compared to medium alone treated cells $(P \leq 0.05)$. Specifically, IL6 expression was increased when exposed to $1 \%$ non-treated, filtered, or heattreated seminal plasma when compared to medium alone (21.4-fold, 13.2-fold, and 1.6-fold, respectively; $P \leq 0.05$ ). Expression of TNF (Fig. 2D) was unaffected following exposure to seminal plasma compared to medium alone, with the exception of a 2.5 -fold increase in expression following exposure to $0.001 \%$ heat-treated seminal plasma $(P \leq 0.05)$.

\section{The acute effect of seminal plasma on BEND cell expression}

The effect of seminal plasma on BEND cell expression was evaluated after exposure to $1 \% \mathrm{v} / \mathrm{v}$ seminal plasma or medium alone for $0,1,3,6$ or $12 \mathrm{~h}$ (Fig. 3). The second pool of seminal plasma collected from 12 unique bulls was used during this and all subsequent experiments. Interestingly, the second pool of seminal plasma was cytotoxic at $5 \% \mathrm{v} / \mathrm{v}$, whereas the first pool was cytotoxic at $1 \% \mathrm{v} / \mathrm{v}$ (Supplementary Fig. $1 \mathrm{~A}$, see section on supplementary data given at the end of this article). Expression of CSF2 (Fig. 3A) or TNF (Fig. 3D) was unaffected following exposure to seminal plasma compared to control cells. Exposure to seminal plasma increased $(P \leq 0.05)$ BEND cell expression of IL1B (Fig. 3B) compared to controls following 1,3 or $6 \mathrm{~h}$ of treatment (increased 2.1-fold, 3.1-fold and 2.4-fold, respectively). Exposure to seminal plasma increased $(P \leq 0.05)$ BEND cell expression of IL6 (Fig. 3C) compared to controls following 1, 3, 6, or $12 \mathrm{~h}$ of treatment (increased 4.1fold, 3.9-fold, 2.5-fold and 5.9-fold, respectively).

\section{The effect of estradiol supplementation on seminal plasma-mediated BEND cell function}

To assess the capacity for estradiol to modulate seminal plasma-induced BEND cell gene expression, cells were exposed to medium alone or 0.001, 0.01, 0.1, or $1 \% \mathrm{v} / \mathrm{v}$ non-treated seminal plasma for $24 \mathrm{~h}$ in the presence of $0.1 \mathrm{nM}$ or $1 \mathrm{nM}$ estradiol (Fig. 4). Cells were supplemented with $0.1 \mathrm{nM}$ or $1 \mathrm{nM}$ of estradiol for $24 \mathrm{~h}$ prior to seminal plasma exposure. The addition of estradiol did not modulate the cytotoxic effects of seminal plasma when compared to estradiol-free cultures (Supplementary Fig. 1). Expression of CSF2 (Fig. 4A) or TNF (Fig. 4D) were unchanged following 


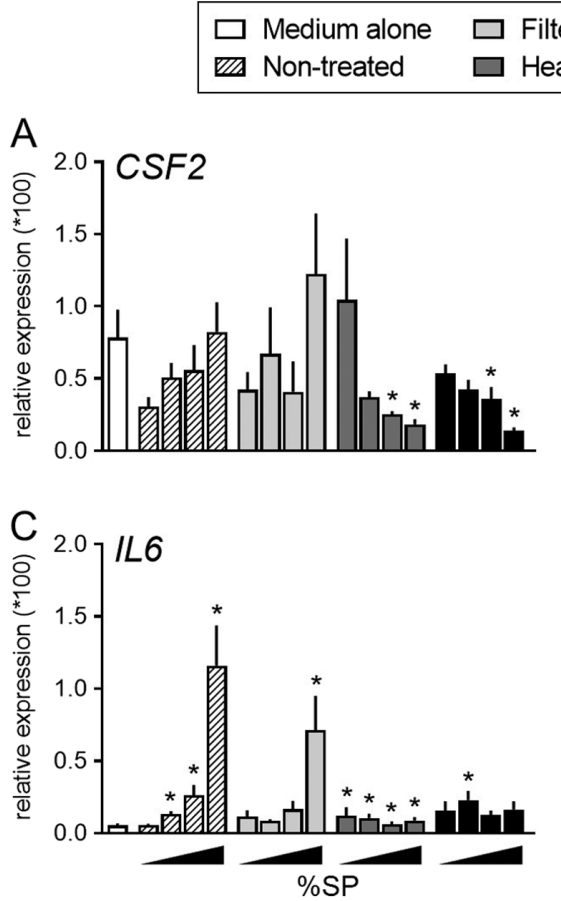

exposure to seminal plasma, regardless of estradiol treatment. Expression of IL1B (Fig. 4B) or IL6 (Fig. 4C) was increased $(P \leq 0.05)$ following exposure to $1 \%$ seminal plasma compared to medium alone; however, this increase was not mediated by estradiol.
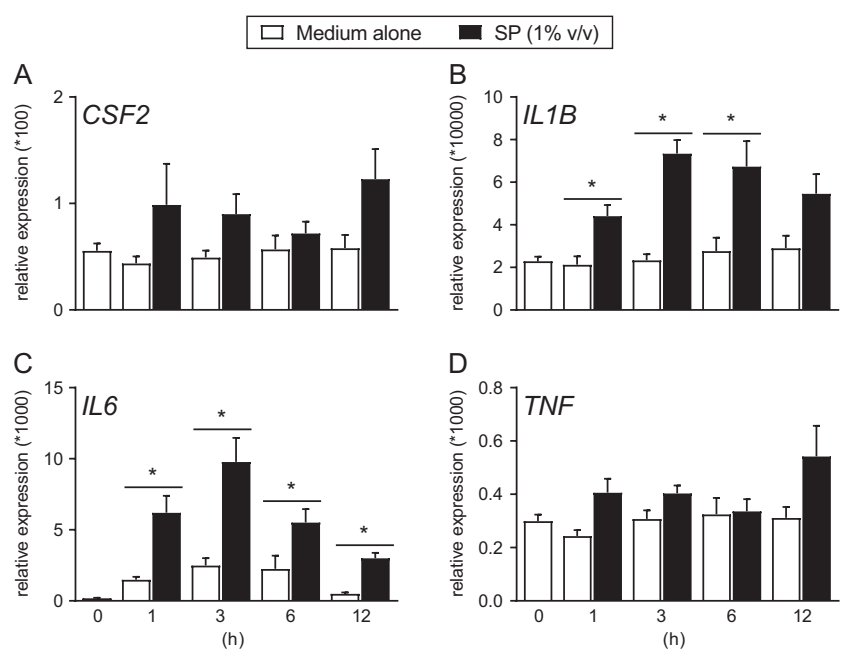

Figure 3 Acute effects of seminal plasma on BEND cell expression. BEND cell expression of CSF2 (A), IL1B (B), IL6 (C), and TNF (D) was evaluated following treatment with medium alone or $1 \% \mathrm{v} / \mathrm{v}$ seminal plasma (SP) for $0,1,3,6$ or $12 \mathrm{~h}$. Data are presented as the mean relative expression normalized to GAPDH using the $2^{-\triangle \mathrm{Ct}}$ method \pm S.E.M. Experiments were replicated in seven independent assays. Data were log transformed and analyzed using the generalized linear mixed model and pairwise comparisons were made at each time point between medium alone and treatment concentration. ${ }^{*}$, represents $P \leq 0.05$.
Figure 2 Effect of seminal plasma on BEND cell gene expression. BEND cell expression of CSF2 (A), IL1B (B), IL6 (C), and TNF (D) was evaluated by qPCR after 24-h treatment with medium alone $(0)$ or $0.001,0.01,0.1$, or $1 \%$ $\mathrm{v} / \mathrm{v}$ seminal plasma (SP). Seminal plasma was either non-treated, filtered, heat-treated, or filtered and heat-treated. Data are presented as mean relative expression normalized to GAPDH using the $2^{-\triangle \mathrm{Ct}}$ method \pm S.E.M. Experiments were replicated in seven independent assays. Data were log transformed and analyzed using the generalized linear mixed model and pairwise comparisons were made between medium alone and each seminal plasma concentration. *, represents $P \leq 0.05$ compared to medium alone.

\section{Evaluation of transforming growth factor $\beta$ content in bovine seminal plasma}

The content of TGF $\beta$ in seminal plasma was evaluated in 33 individual bulls (Supplementary Fig. 2). Total TGF $\beta-1$ and TGF $\beta-2$ was detectable at an average concentration of $7.11 \pm 1.55$ and $6.07 \pm 1.16 \mathrm{ng} / \mathrm{mL}$, respectively (range of $0.16-33.31$ and $0.00-27.36 \mathrm{ng} / \mathrm{mL}$, respectively). Bioactive TGF $\beta-1$ and TGF $\beta-2$ was detectable at an average concentration of $5.38 \pm 0.88$ and $331.09 \pm 146.33 \mathrm{pg} / \mathrm{mL}$, respectively (range of $0.00-28.56$ and $0.00-4398.18 \mathrm{pg} / \mathrm{mL}$, respectively). An average of $0.37 \pm 0.12 \%$ of TGF $\beta-1$ and an average of $4.15 \pm 1.62 \%$ of TGF $\beta-2$ was present in seminal plasma in the bioactive form. Using ejaculate volume and the concentration of total TGF $\beta$, we calculated the absolute content of TGF $\beta-1(63.4 \pm 15.6 \mathrm{ng})$ and TGF $\beta-2$ $(58.2 \pm 11.2 \mathrm{ng})$ in individual ejaculates.

\section{The effect of transforming growth factor $\beta$ on BEND cell function}

The effect of rhTGF $\beta-1$ (1, 10, or $100 \mathrm{ng} / \mathrm{mL})$, or rhTGF $\beta-2(0.1,1$, or $10 \mathrm{ng} / \mathrm{mL})$ on BEND cell viability was assessed following 24-h exposure in medium supplemented with 0.1 or $1 \mathrm{nM}$ estradiol. Regardless of estradiol supplementation, rhTGF $\beta-1$ or rhTGF $\beta-2$ had no effect on BEND cell viability compared to controls (Supplementary Fig. 3).

Expression of BEND cell CSF2, IL1B, IL6, and TNF was evaluated after 24-h exposure to rhTGF $\beta-1$, rhTGF $\beta$-2 or medium alone (Fig. 5). In the absence of estradiol, expression of TNF (Fig. 5D and $\mathrm{H}$ ) was 

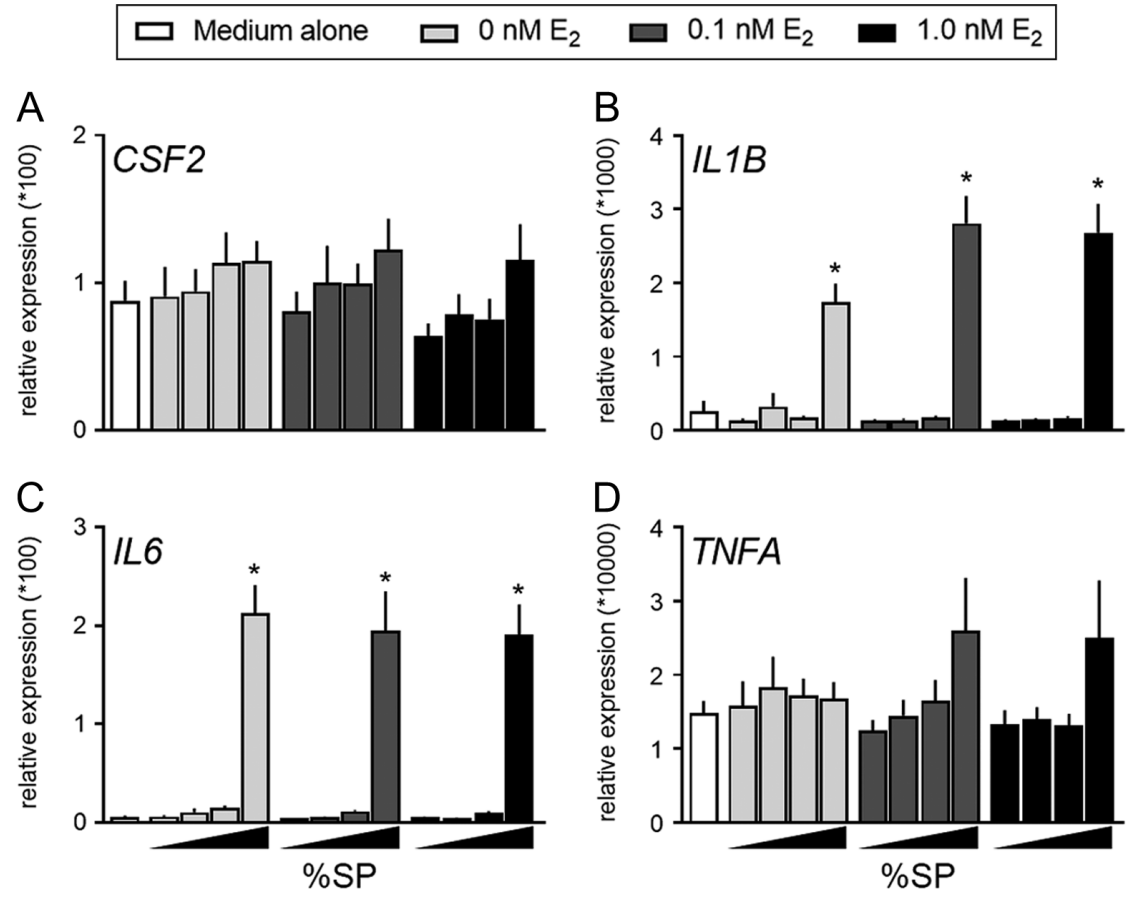

Figure 4 Effect of seminal plasma and estradiol on BEND cell gene expression. BEND cell expression of CSF2 (A), IL1B (B), IL6 (C), and $T N F(D)$ was evaluated by qPCR. BEND cells were cultured in the presence of either $0,0.1$, or $1 \mathrm{nM}$ estradiol for $24 \mathrm{~h}$ before the addition of seminal plasma (SP). BEND cells were then treated with $0.001,0.01,0.1$, or $1 \mathrm{v} / \mathrm{v}$ SP for $24 \mathrm{~h}$ in medium supplemented with estradiol. Medium alone was used as a negative control. Data are presented as mean relative expression normalized to GAPDH using the $2^{-\Delta C t}$ method \pm S.E.M. Experiments were replicated in eight independent assays. Data were log transformed and analyzed using the generalized linear mixed model and pairwise comparisons were made between medium alone and each treatment. ${ }^{*}$, represents $P \leq 0.05$ compared to medium alone.

increased following exposure to rhTGF $\beta$-1 or rhTGF $\beta$ - 2 compared to controls $(P \leq 0.05)$, but not when medium was supplemented with estradiol. Interestingly, in the presence of estradiol, BEND cell expression of IL6 (Fig. $5 \mathrm{C}$ and $\mathrm{G}$ ) was increased following exposure to rhTGF $\beta-1$ or rhTGF $\beta-2$ compared to controls $(P \leq 0.05)$, but not when estradiol was absent. Exposure of BEND cells to rhTGF $\beta-1$ had no effect on CSF2 or IL1B (Fig. 5A and $B)$ expression regardless of estradiol supplementation. Conversely, expression of CSF 2 and IL1B were reduced $(P \leq 0.05)$ following exposure to rhTGF $\beta-2$ in the presence of $0.1 \mathrm{nM}$ estradiol (Fig. 5E and F).

\section{$\square 0 \mathrm{nME}_{2} \square 0.1 \mathrm{nME}_{2} \square 1.0 \mathrm{nME}_{2}$}
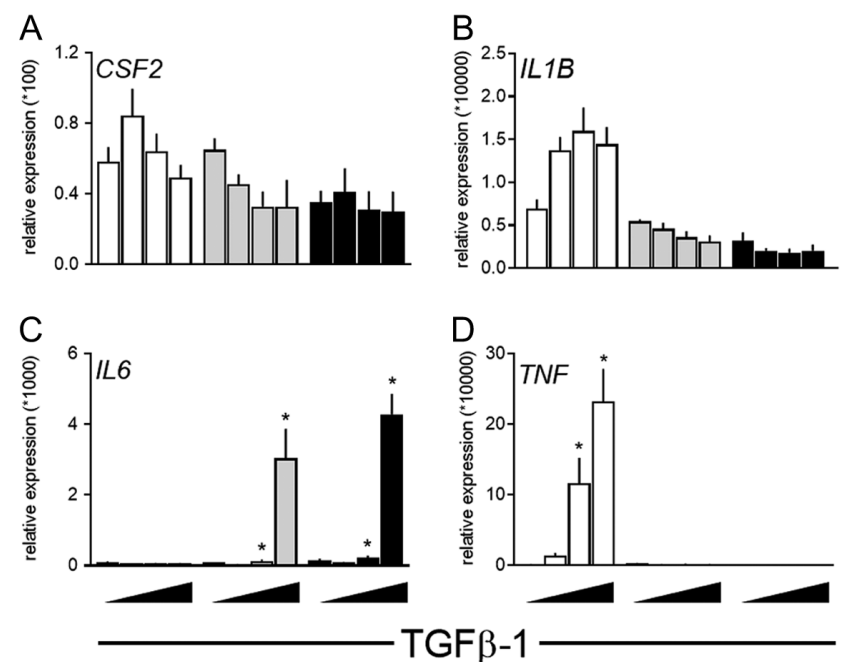
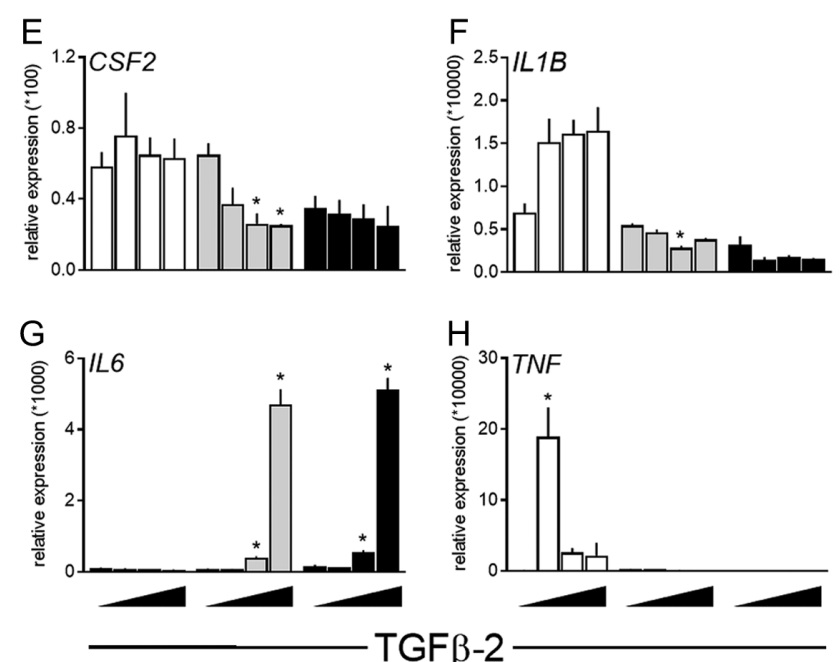

Figure 5 Effect of transforming growth factor $\beta$ on BEND cell gene expression. BEND cell expression of CSF2 (A and E), IL1B (B and F), IL6 (C and $\mathrm{G})$, and TNF (D and $\mathrm{H}$ ) was evaluated by qPCR. BEND cells were cultured in the presence of $0,0.1$ or $1 \mathrm{nM}$ estradiol for $24 \mathrm{~h}$ before addition of rhTGF $\beta$. BEND cells were then exposed to either $\operatorname{rhTGF} \beta-1(0,1,10$ or $100 \mathrm{ng} / \mathrm{mL} ; \mathrm{A}, \mathrm{B}, \mathrm{C}, \mathrm{D})$, or rhTGF $\beta-2(0.1,1 \mathrm{or} 10 \mathrm{ng} / \mathrm{mL}$; E, F, $\mathrm{G}, \mathrm{H}$ ) for $24 \mathrm{~h}$ in medium supplemented with estradiol. Data are presented as mean relative expression normalized to GAPDH using the $2^{-\triangle \mathrm{Ct}}$ method \pm S.E.M. Experiments were replicated in at least four independent assays. Data were log transformed and analyzed using the generalized linear mixed model and pairwise comparisons were made with the $0 \mathrm{ng} / \mathrm{mL}$ control within each estradiol concentration. *, represents $P \leq 0.05$ compared to appropriate control within an estradiol concentration. 

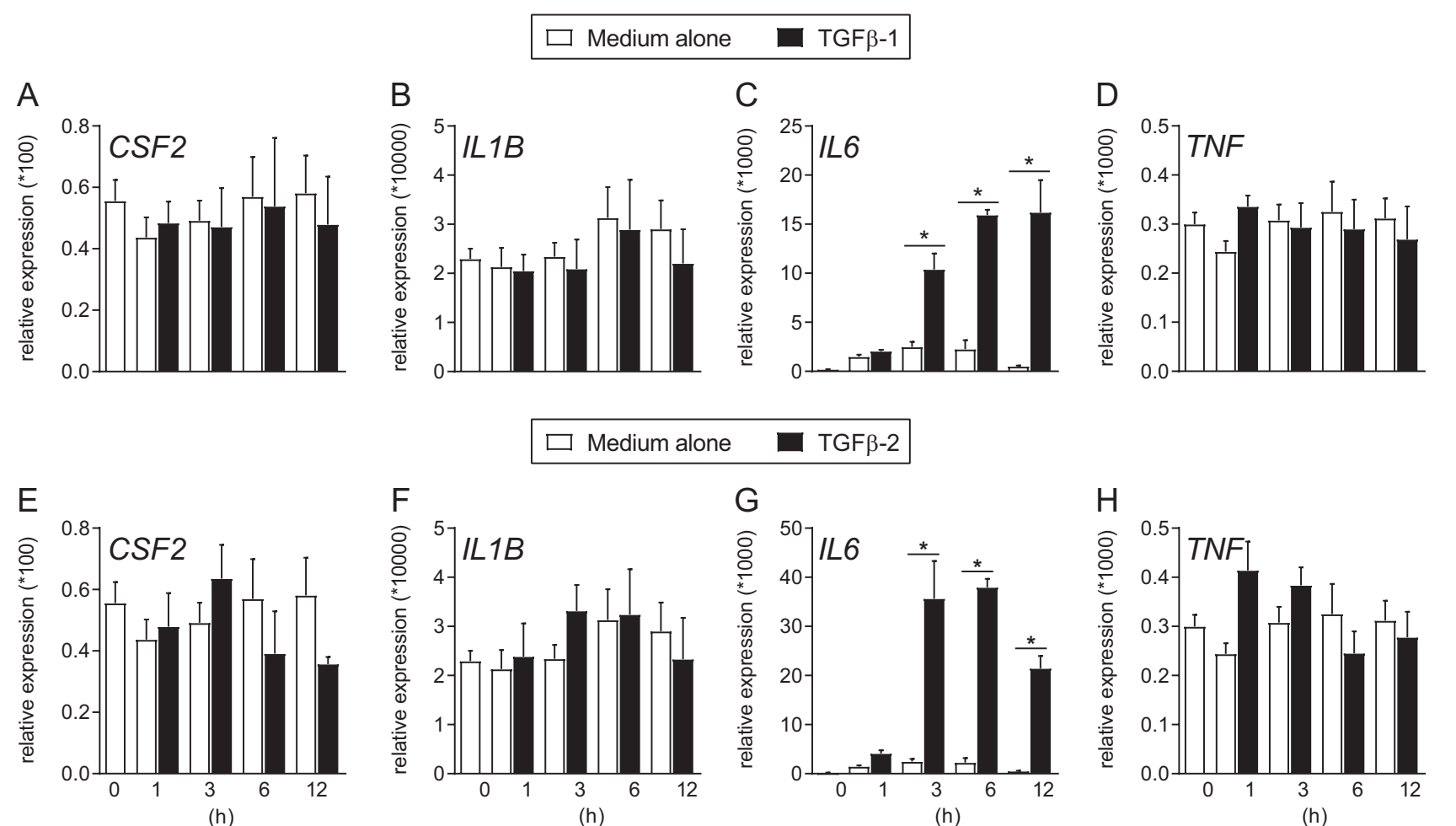

Figure 6 Acute effects of transforming growth factor $\beta$ on BEND cell gene expression. Expression of CSF2 (A and E), IL1B (B and F), IL6 (C and G) and $T N F(D$ and $H)$ in response to $\operatorname{rhTGF} \beta-1(\mathrm{~A}, \mathrm{~B}, \mathrm{C}$ and $\mathrm{D})$ or $\operatorname{rhTGF} \beta-2(\mathrm{E}, \mathrm{F}, \mathrm{G}$ and $\mathrm{H})$. BEND cells were treated with either medium alone, $100 \mathrm{ng} / \mathrm{mL}$ rhTGF $\beta-1$, or $10 \mathrm{ng} / \mathrm{mL}$ rhTGF $\beta-2$ for $0,1,3,6$ or $12 \mathrm{~h}$. Culture medium was supplemented with $0.1 \mathrm{nM}$ estradiol for $24 \mathrm{~h}$ prior to and during treatments. Data are presented as the mean relative expression normalized to GAPDH using the $2^{-\Delta C \mathrm{Ct}}$ method \pm S.E.M. Experiments were replicated in at least four independent assays. Data were log transformed and analyzed using the generalized linear mixed model and pairwise comparisons were made at each time point between medium alone and treatment. ${ }^{*}$, represents $P \leq 0.05$.

The acute response of BEND cells to rhTGF $\beta-1$ (100 $\mathrm{ng} / \mathrm{mL})$, or rhTGF $\beta-2(10 \mathrm{ng} / \mathrm{mL})$ was evaluated following exposure for $0,1,3,6$, or $12 \mathrm{~h}$ in medium supplemented with $0.1 \mathrm{nM}$ estradiol (Fig. 6). Exposure to rhTGF $\beta-1$ or rhTGF $\beta-2$ had no effect on BEND expression of CSF2, IL1B or TNF at any time point (Fig. 6). However, expression of IL6 was increased $(P \leq 0.05)$ after exposure to rhTGF $\beta-1$ or rhTGF $\beta-2$ for 3,6 and $12 \mathrm{~h}$ compared to controls (Fig. 6C and G).

\section{Effect of neutralizing seminal plasma transforming growth factor $\beta$ on BEND cell gene expression}

To determine the degree to which seminal plasma TGF $\beta$ modulates BEND cell gene expression, seminal plasma was pre-incubated with TGF $\beta$ neutralizing antibody $(\alpha \mathrm{TGF} \beta)$ prior to application to BEND cells. Expression of CSF2, IL1B, IL6 and TNF was evaluated by qPCR following 24-h treatment (Fig. 7). All cells were cultured in the presence of $0.1 \mathrm{nM}$ estradiol before and during treatments.

Seminal plasma induced a 28.4-fold increase in BEND cell IL6 expression (Fig. 7C). The addition of $20 \mu \mathrm{g} / \mathrm{mL}$ of $\alpha \mathrm{TGF} \beta$ inhibited seminal plasma induced IL6 expression by $49.5 \%$ compared to cells exposed to seminal plasma alone $(P \leq 0.05)$. Seminal plasma induced a 9.3 -fold increase in $I L 1 B$ expression $(P \leq 0.05)$ which was not affected by the addition of $\alpha$ TGF $\beta$ (Fig. 7B). As previous, seminal plasma did not alter BEND cell expression of CSF2 or TNF (Fig. 7A and D).

\section{Effect of seminal plasma or transforming growth factor $\beta$ on primary endometrial stromal and epithelial cell gene expression}

The capacity of seminal plasma or TGF $\beta$ to modulate expression of CSF2, IL1B, IL6 or TNF was assessed in primary bovine endometrial stroma (Fig. 8A, B, C and D) or epithelial cells (Fig. 8E, F, G and H). Cells were exposed to seminal plasma $(0.001,0.01,0.1$, or $1 \%$ $\mathrm{v} / \mathrm{v})$, $\operatorname{rhTGF} \beta-1(1,10$ or $100 \mathrm{ng} / \mathrm{mL}), \operatorname{rhTGF} \beta-2(0.1$, 1 or $10 \mathrm{ng} / \mathrm{mL}$ ), or medium alone for $24 \mathrm{~h}$. Stromal cell expression of CSF2, IL6 and TNF were increased $(P \leq 0.05)$ following exposure to $1 \%$ seminal plasma compared to control cells (11.0-fold, 28.4-fold and 63.1 -fold, respectively). Seminal plasma had no effect on epithelial cell gene expression. Exposure to rhTGF $\beta$ - 1 or rhTGF $\beta-2$ had no effect on either endometrial stromal or epithelial cells. 

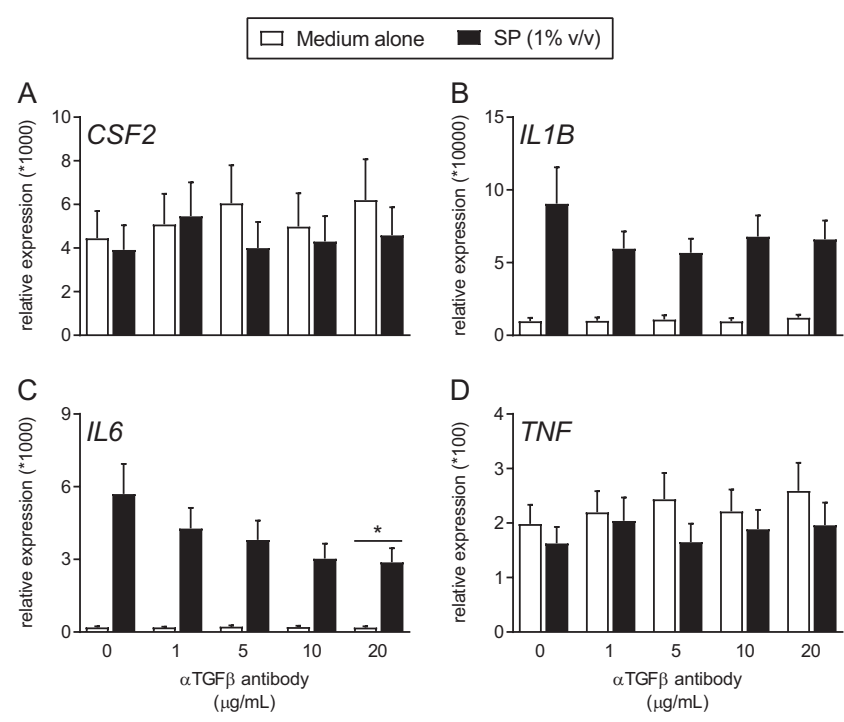

Figure 7 Effects of neutralizing transforming growth factor $\beta$ antibody on seminal plasma induced gene expression. Expression of CSF2 (A), IL1B (B), IL6 (C), and TNF (D) was evaluated by qPCR. BEND cells were cultured in the presence of $0.1 \mathrm{nM}$ estradiol for $24 \mathrm{~h}$ before addition of treatments. BEND cells were then treated with medium alone or $1 \% \mathrm{v} / \mathrm{v}$ seminal plasma (SP) in the presence of pan-TGF $\beta$ neutralizing antibody. Treatments were pre-incubated with 1, 5, 10, or $20 \mu \mathrm{g} / \mathrm{mL}$ of antibody for 5 min prior to exposure of cells for $24 \mathrm{~h}$. Data are presented as the mean relative expression normalized to $G A P D H$ using the $2^{-\triangle C \mathrm{Ct}}$ method \pm S.E.M. Experiments were replicated in six independent assays. Data were analyzed using the generalized linear mixed model and pairwise comparisons were made between SP and medium alone within a given antibody concentration. *, represents $P \leq 0.05$.

\section{Effect of intrauterine infusion of semen components on endometrial gene expression}

Endometrial response to saline, washed sperm, seminal plasma or rhTGF $\beta-1$ was evaluated $12 \mathrm{~h}$ following intrauterine infusion (Fig. 9). The average number of lactations and the average number of days postpartum at the time of infusion was similar among treatment groups $(2.4 \pm 0.2$ lactations and $448 \pm 24.4$ days postpartum; $P>0.05)$. Endometrial expression of CSF2, IL1B, IL6 and TNF was unchanged $(P>0.05)$ following intrauterine infusion of any treatment.

\section{Discussion}

Since the 1960s, post-coital inflammation has been characterized in rodents, humans, horse, and swine (Yanagimachi \& Chang 1963, O et al. 1988, Robertson \& Seamark 1992, Troedsson et al. 2001, O'Leary et al. 2004, Sharkey et al. 2007). Our own work demonstrates that seminal plasma increases the expression of inflammatory mediators in bovine primary cultures (Ibrahim et al. 2019). Reports from mice have shown that seminal plasma exposure at coitus is associated with modulating pregnancy outcomes and subsequent offspring performance (Bromfield et al. 2014). Initial investigations into post-coital endometrial inflammation defined seminal vesicle gland-derived TGF $\beta$ as the active moiety responsible for maternal inflammation at the time of insemination (Robertson et al. 1997). Due to the increased utilization of artificial insemination in the cattle industry, we proposed to further investigate
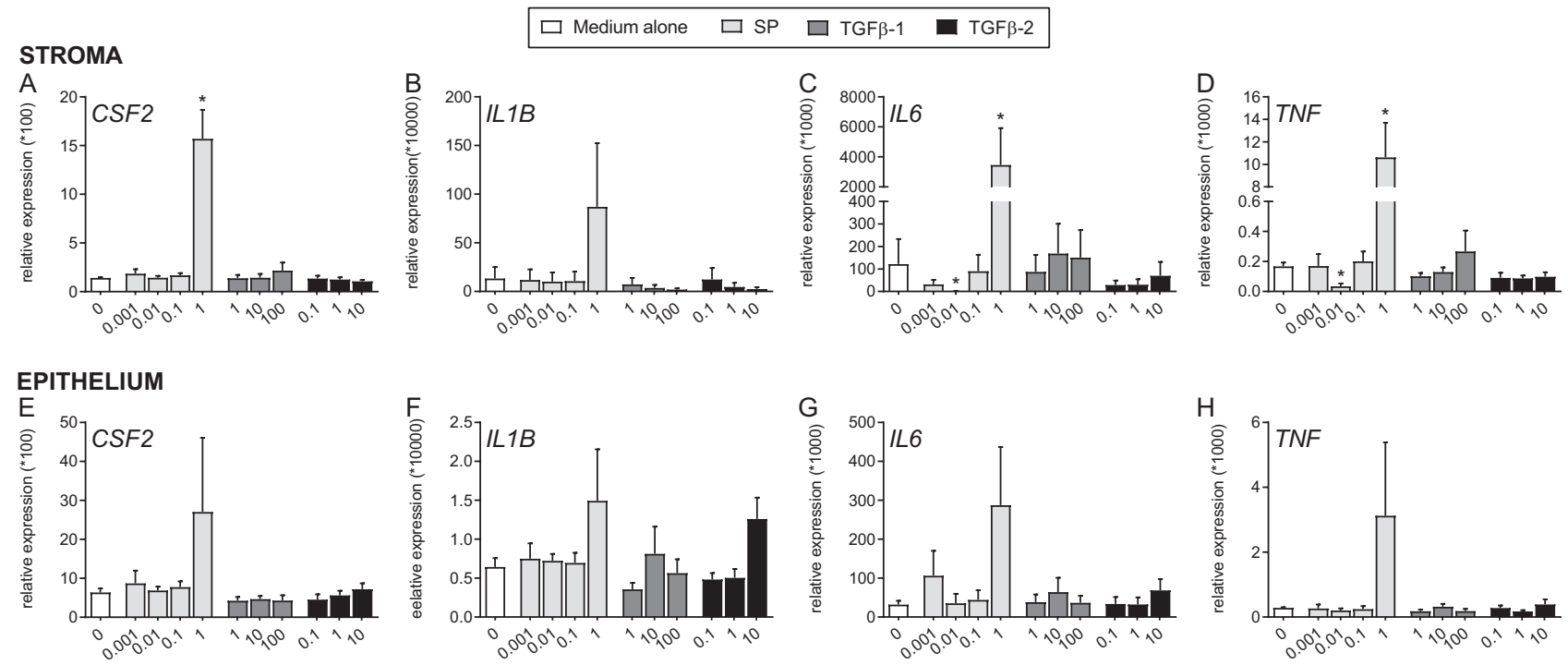

Figure 8 Effect of seminal plasma or transforming growth factor $\beta$ on primary endometrial cell gene expression. Expression of CSF2, IL1B, IL6 and TNF was evaluated in primary endometrial stromal (A, B, C and D) or epithelial (E, F, G and H) cells after 24-h treatment with either seminal plasma $(\mathrm{SP} ; 0.001,0.01,0.1$, or $1 \% \mathrm{v} / \mathrm{v})$, rhTGF $\beta-1(1,10$ or $100 \mathrm{ng} / \mathrm{mL})$, rhTGF $\beta-2(0.1,1$ or $10 \mathrm{ng} / \mathrm{mL})$ or medium alone. Data are presented as the mean relative expression normalized to GAPDH using the $2^{-\triangle C t}$ method \pm s.E.M. Experiments include six independent assays with each replicate of cells obtained from an individual cow. Data were log transformed and analyzed using the generalized linear mixed model and pairwise comparisons were made between medium alone and each treatment. *, represents $P \leq 0.05$ compared to medium alone. 

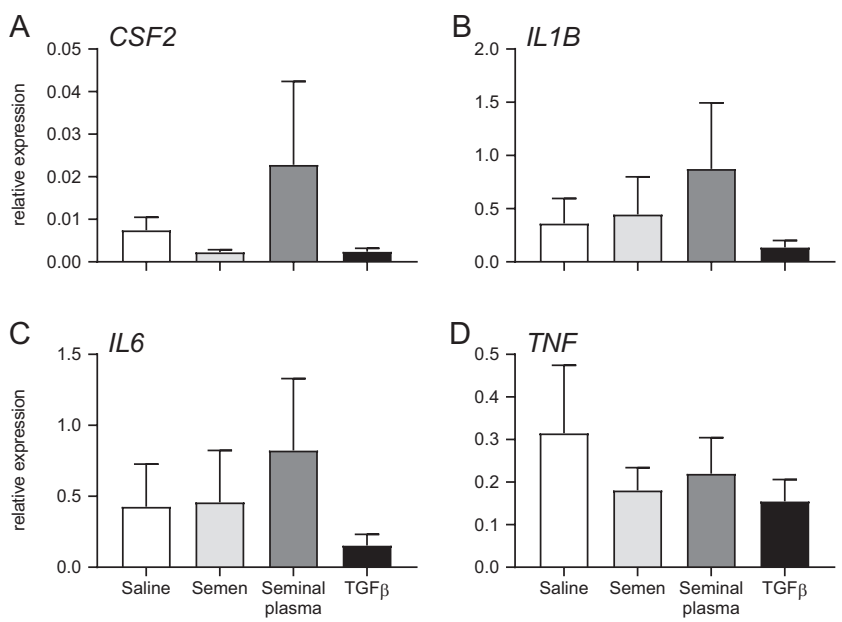

Figure 9 Effect of intrauterine infusion of semen components on endometrial gene expression. Expression of CSF2 (A), IL1B (B), IL6 (C) and TNF (D) was evaluated in endometrial tissue collected by cytobrush $12 \mathrm{~h}$ after intrauterine infusion with $0.5 \mathrm{~mL}$ of either saline, washed sperm, seminal plasma, or $10 \mathrm{ng}$ of rhTGF $\beta-1$. Each treatment was infused into five individual cows at the time of behavioral estrous. Data are presented as the mean relative expression normalized to GAPDH using the $2^{-\Delta C t}$ method \pm S.E.M. Data were $\log$ transformed and analyzed using the generalized linear mixed model and pairwise comparisons were made between each treatment.

the role of semen components in modulating the postcoital maternal environment. Using the cell line, BEND cells, we initially observed a heat-labile cytotoxic effect of seminal plasma starting from $1 \% \mathrm{v} / \mathrm{v}$. Subsequently, we observed a seminal plasma-induced increase in $I L 1 B$ and IL6 BEND cell expression which was independent of estradiol exposure. In addition, we tested the capacity of TGF $\beta$ to elicit endometrial change, as observed in other species. While seminal plasma increased expression of CSF2, IL6 and TNF in primary endometrial cells, TGF $\beta$ had no effect. However, both TGF $\beta-1$ and TGF $\beta-2$ increased BEND cell expression of IL6 in an estradiol-dependent manner, while TNF was increased only in the absence of estradiol. Blocking seminal plasma TGF $\beta$ reduced the capacity of BEND cells to increase IL6 expression but did not inhibit expression entirely. Interestingly we did not observe any effect on endometrial gene expression following intrauterine infusion of semen components.

The natural site of semen deposition in cattle is the fornix vagina and sperm travel through the cervix into the uterus, while most seminal plasma remains in the vagina and is lost through retrograde transport. It is unclear how much, if any, seminal plasma is delivered into the uterus in cattle, whereas horses and swine receive a large dose of seminal plasma directly into the uterine lumen. These anatomical differences of conception could influence the dynamics by which the female reproductive tract communicates with semen components. However, artificial insemination bypasses the cervix and results in extended semen being delivered directly into the uterus. Current semen extension protocols result in commercial semen doses containing variable concentrations of seminal plasma (Bergeron et al. 2004). In this regard caution must be applied when interpreting the results of the above studies when extrapolating to the physiological response to natural insemination. The studies described herein bypass the physiological site of semen deposition which may be important, or perhaps endometrial response requires simultaneous exposure to both seminal plasma and sperm to elicit endometrial responses? We are relatively confident that the timing of exposure to semen components was optimal given that cows were observed at estrus when circulating estrogen is maximal and has been previously described as being critical for seminal plasma elicited responses in the endometrium of rodents (Robertson \& Seamark 1990). However, future experimental approaches should utilize a time course approach to ensure that any semenmediated response is evaluated in the endometrium; it may be possible that a 12-h delay between treatment and sampling is too protracted to evaluate any response. Although our previous intra-uterine infusion of seminal plasma suggests that an endometrial response was apparent at $24 \mathrm{~h}$ post infusion (Ibrahim et al. 2019).

There are several points at which pregnancy can fail. Elegant studies in cattle suggest that $40 \%$ of pregnancy failure occurs within 1 week of conception (Santos et al. 2004, Wiltbank et al. 2016). This suggests that early pregnancy loss is a result of fertilization errors, embryonic failure, endometrial failure or ovarian insufficiency; theoretically, seminal plasma could influence these factors based on observations made in other species. In rodents, seminal plasma increases the expression of endometrial embryokine expression to support preimplantation embryo development, while modulating maternal immune cell populations to facilitate the implantation and invasion of the semiallogeneic conceptus. In rodents and swine, seminal plasma exposure mediates ovarian function by increasing progesterone synthesis or altering immune cells within the corpus luteum (Gangnuss et al. 2004, O'Leary et al. 2002, 2006). Unprotected intercourse at the time of embryo transfer, or seminal plasma exposure during IVF treatment increases clinical pregnancy rates in women (Tremellen et al. 2000, Saccone et al. 2019). It is unclear if seminal plasma can facilitate the same effect on pregnancy success in cattle. However, we have demonstrated that supplementation of seminal plasma at the time of artificial insemination increases birth weight of heifer calves, but does not influence conception rates (Ortiz et al. 2019). Our previous in vitro data suggest that seminal plasma has the potential to increase the expression of embryokines such as CSF2 and IL6 to support the preimplantation bovine embryo (de Moraes \& Hansen 1997, Ibrahim et al. 2019, Wooldridge \& Ealy 2019). Identification of factors in seminal plasma, such as TGF $\beta$, which could modulate these key time points in pregnancy may lead to intervention strategies that could 
be supplemented at artificial insemination and improve pregnancy outcomes in cattle. Murine seminal plasma contains predominately TGF $\beta-1$ and TGF $\beta-2$ isoforms and elicits endometrial inflammation similar to that induced by seminal plasma exposure (Robertson 2005). TGF $\beta-1, T G F \beta-2$ and TGF $\beta-3$ are plentiful in human seminal plasma and stimulate inflammatory changes in ectocervical epithelial cells, mimicking the post coital uterine environment (Sharkey et al. 2012a). We found that bull seminal plasma contains TGF $\beta-1$ and TGF $\beta-2$ in both active and latent forms. Following insemination in mice, $70 \%$ of TGF $\beta$ in uterine fluid is present in the active form, suggesting that activation of TGF $\beta$ occurs at the time of ejaculation or after deposition in the female tract (Tremellen et al. 1998). In human, the acidic environment of the vagina ( $\mathrm{pH}$ 5.0) could be enough to remove TGF-binding protein and activate latent protein. Latent seminal plasma TGF $\beta$ may also involve seminal plasma enzymes, including plasmin, subtilisin-like endoproteases and urokinase type plasminogen activator (Chu \& Kawinski 1998, Robertson et al. 2002). In regard to the content of TGF $\beta$ comparisons to other species can be confounded by ejaculate volume and site of semen deposition. Here we report the absolute content of bull semen TGF $\beta-1$ and TGF $\beta-2$ as $63 \mathrm{ng}$ and $58 \mathrm{ng}$, respectively. Comparatively, human seminal plasma contains $220-240 \mathrm{ng} / \mathrm{mL}$ and $5-18 \mathrm{ng} / \mathrm{mL}$ of TGF $\beta-1$ and TGF $\beta$-2 (Nocera \& Chu 1995), while mouse and swine semen TGF $\beta-1$ content has been estimated at $74 \mathrm{ng} /$ $\mathrm{mL}$ and $150 \mathrm{ng} / \mathrm{mL}$, respectively (Tremellen et al. 1998, O'Leary et al. 2011). Interestingly, neutralizing seminal plasmaTGF $\beta$, by use of a pan-specific antibody, mediated a moderate reduction in IL6 gene expression, future experiments should clarify this response using inhibitors of TGF $\beta$ signaling or increased incubation time of seminal plasma with blocking antibodies. Additionally, future experiments should evaluate the secretion of bioactive molecules into cell culture supernatants and uterine fluid following treatment with semen components.

Here bovine seminal plasma has a heat-labile cytotoxic effect on BEND cells, implying that cytotoxicity is protein mediated. Cytotoxicity of bovine seminal plasma has been previously reported at high concentrations $(4 \% \mathrm{v} / \mathrm{v})$ in primary endometrial cells and is associated with fertility, with low fertility bulls increasing cytotoxicity (Nongbua et al. 2018). In addition, it has been reported that the protein content of semen is associated with pregnancy rate, with low protein abundance associated with low conception rate (Moura et al. 2006). Unique to the bull is the expression of bovine seminal RNase Jermann et al. 1995). In addition to the immunosuppressive function of bovine seminal RNase (Tamburrini et al. 1990), this enzyme has been shown to have direct cytotoxic activity (Matousek et al. 2003, Viola et al. 2005). Interestingly, we observed that the cytotoxic potential of seminal plasma varied between the two unique populations of bulls used in the current study, with the first population of bulls exhibiting toxicity at lower concentrations than the second population of bulls. This effect may be due to variability in semen constituents between individuals driven by genetic variability, season of collection, feed, exposure to toxins, presence of bacterial toxins or bull age. Future studies should utilize seminal plasma from individual bulls to isolate the cytotoxic components of semen; seminal plasma cytotoxicity may be associated with bull fertility.

Previous analysis of bull semen reports that osteopontin and lipocalin-type prostaglandin D synthase content of seminal plasma is positively associated with increased bull fertility (Cancel et al. 1997, Gerena et al. 1998). The role for either protein is currently unknown but may play a role in sperm function or sperm-uterine interactions. Conversely, seminal plasma derived TGF $\beta$ is the active molecule in semen to drive postcoital inflammation and maternal cytokine expression in rodents and humans (Tremellen et al. 1998, Sharkey et al. 2012a). Intrauterine supplementation with 40 ng of rhTGF $\beta-1$ at the time of artificial insemination increased conception rates in beef cattle herds with poor fertility but had no effect on herds when conception was above 50\% (Odhiambo et al. 2009).

Our data indicate that seminal plasma-mediated increased expression of BEND cell ILIB and IL6 is independent of estradiol, while TGF $\beta-1$ or TGF $\beta-2$ increased BEND cell IL6 expression in an estradioldependent manner. Conversely, neither TGF $\beta-1$ nor TGF $\beta$-2 increased expression of any cytokine measured in primary cells. These discrepancies may be a direct reflection of the cell types used in each experiment. BEND cells were isolated from cows at day 14 of the estrous cycle and are presumed to be positive for bovine diarrheal virus (Johnson et al. 1999), whereas primary endometrial cells cultured here were isolated at days 11-17 of the estrous cycle based on ovarian morphology. The responsiveness of these two cells types to estrogen is questionable, as is their capacity to respond to human recombinant TGF $\beta$ protein. Additionally, the transformation of BEND cells or longterm culture may impair responsiveness to a degree which does not recapitulate primary isolated cells which would be exposed to semen components at insemination under the same endocrine environment. Interestingly, we found that the cytotoxicity of seminal plasma varied between batches, and it is very likely that responsiveness of cells to seminal plasma may change due to the presence or absence of specific bulls within the sampled population. Interestingly, our previous data reported that seminal plasma increased endometrial expression of various inflammatory cytokines that was only mildly recapitulated in these current studies with primary cells. The source of seminal plasma is likely the root cause of this discrepancy and may require the testing of individual bulls for endometrial responsiveness. 
The utility of artificial reproductive technologies clearly demonstrates that seminal plasma is not a requirement for pregnancy. However, work in various other species suggests that paternal factors can modulate endometrial function and potentially influence pregnancy outcomes. The heavy use of artificial insemination in the cattle industry, where insemination occurs in the absence of (or very dilute) seminal plasma, may provide an opportunity to improve pregnancy outcomes by simple supplementation of paternal factors at the time of insemination. These studies begin to describe paternal seminal factors that could be tested in cell lines and potentially targeted for further investigation to improve reproductive performance of cattle.

\section{Supplementary data}

This is linked to the online version of the paper at https://doi.org/10.1530/REP-19-0421.

\section{Declaration of interest}

The authors declare that there is no conflict of interest that could be perceived as prejudicing the impartiality of the research reported.

\section{Funding}

Research reported here was supported by the Southeast Milk checkoff and Select Sires, Plain City, OH, USA.

\section{Author contribution statement}

J J B conceived the study. J A R and J J B wrote the paper and analyzed data. J A R, L A I, B R H, P C C M and R L P performed experiments.

\section{Acknowledgements}

The authors would like to thank Select Sires for their continued support. The authors would also like to thank all the staff of the University of Florida Dairy Research Unit, specifically Todd Pritchard and Miguel Torrado Vazquez.

\section{References}

Bergeron A, Crete MH, Brindle Y \& Manjunath P 2004 Low-density lipoprotein fraction from hen's egg yolk decreases the binding of the major proteins of bovine seminal plasma to sperm and prevents lipid efflux from the sperm membrane. Biology of Reproduction 70 708-717. (https://doi.org/10.1095/biolreprod.103.022996)

Bromfield JJ, Schjenken JE, Chin PY, Care AS, Jasper MJ \& Robertson SA 2014 Maternal tract factors contribute to paternal seminal fluid impact on metabolic phenotype in offspring. PNAS 111 2200-2205. (https://doi. org/10.1073/pnas.1305609111)

Cancel AM, Chapman DA \& Killian GJ 1997 Osteopontin is the 55-kilodalton fertility-associated protein in Holstein bull seminal plasma. Biology of Reproduction 57 1293-1301. (https://doi.org/10.1095/ biolreprod57.6.1293)
Cardoso B, Oliveira ML, Pugliesi G, Batista E \& Binelli M 2017 Cytobrush: a tool for sequential evaluation of gene expression in bovine endometrium. Reproduction in Domestic Animals=Zuchthygiene 52 1153-1157. (https://doi.org/10.1111/rda.13037)

Chen W, Jin W, Hardegen N, Lei KJ, Li L, Marinos N, Mcgrady G \& Wahl SM 2003 Conversion of peripheral CD4+CD25- naive T cells to CD4+CD25+ regulatory $T$ cells by TGF-beta induction of transcription factor Foxp3. Journal of Experimental Medicine 198 1875-1886. (https:// doi.org/10.1084/jem.20030152)

Chu TM \& Kawinski E 1998 Plasmin, substilisin-like endoproteases, tissue plasminogen activator, and urokinase plasminogen activator are involved in activation of latent TGF-beta 1 in human seminal plasma. Biochemical and Biophysical Research Communications 253 128-134. (https://doi.org/10.1006/bbrc.1998.9760)

Cronin JG, Turner ML, Goetze L, Bryant CE \& Sheldon IM 2012 Toll-like receptor 4 and MYD88-dependent signaling mechanisms of the innate immune system are essential for the response to lipopolysaccharide by epithelial and stromal cells of the bovine endometrium. Biology of Reproduction 86 51. (https://doi.org/10.1095/biolreprod.111.092718)

de Moraes AA \& Hansen PJ 1997 Granulocyte-macrophage colonystimulating factor promotes development of in vitro produced bovine embryos. Biology of Reproduction 57 1060-1065. (https://doi. org/10.1095/biolreprod57.5.1060)

Fridlender ZG, Sun J, Kim S, Kapoor V, Cheng G, Ling L, Worthen GS \& Albelda SM 2009 Polarization of tumor-associated neutrophil phenotype by TGF-beta: 'N1' versus 'N2' TAN. Cancer Cell 16 183-194. (https://doi. org/10.1016/j.ccr.2009.06.017)

Gangnuss S, Sutton-Mcdowall ML, Robertson SA \& Armstrong DT 2004 Seminal plasma regulates corpora lutea macrophage populations during early pregnancy in mice. Biology of Reproduction 71 1135-1141. (https://doi.org/10.1095/biolreprod.104.027425)

Gerena RL, Irikura D, Urade Y, Eguchi N, Chapman DA \& Killian GJ 1998 Identification of a fertility-associated protein in bull seminal plasma as lipocalin-type prostaglandin D synthase. Biology of Reproduction $\mathbf{5 8}$ 826-833. (https://doi.org/10.1095/biolreprod58.3.826)

Ghiringhelli F, Puig PE, Roux S, Parcellier A, Schmitt E, Solary E, Kroemer G, Martin F, Chauffert B \& Zitvogel L 2005 Tumor cells convert immature myeloid dendritic cells into TGF-beta-secreting cells inducing CD4+CD25+ regulatory $\mathrm{T}$ cell proliferation. Journal of Experimental Medicine 202 919-929. (https://doi.org/10.1084/jem.20050463)

Gutsche S, Von Wolff M, Strowitzki T \& Thaler CJ 2003 Seminal plasma induces mRNA expression of IL-1beta, IL-6 and LIF in endometrial epithelial cells in vitro. Molecular Human Reproduction 9 785-791. (https://doi.org/10.1093/molehr/gag095)

Hansen PJ, Dobbs KB \& Denicol AC 2014 Programming of the preimplantation embryo by the embryokine colony stimulating factor 2. Animal Reproduction Science 149 59-66. (https://doi.org/10.1016/j. anireprosci.2014.05.017)

Ibrahim LA, Rizo JA, Fontes PLP, Lamb GC \& Bromfield JJ 2019 Seminal plasma modulates expression of endometrial inflammatory meditators in the bovinet. Biology of Reproduction 100 660-671. (https://doi. org/10.1093/biolre/ioy226)

Ireland JJ, Murphee RL \& Coulson PB 1980 Accuracy of predicting stages of bovine estrous cycle by gross appearance of the corpus luteum. Journal of Dairy Science 63 155-160. (https://doi.org/10.3168/jds. S0022-0302(80)82901-8)

Jermann TM, Opitz JG, Stackhouse J \& Benner SA 1995 Reconstructing the evolutionary history of the artiodactyl ribonuclease superfamily. Nature 374 57-59. (https://doi.org/10.1038/374057a0)

Johnson GA, Austin KJ, Collins AM, Murdoch WJ \& Hansen TR 1999 Endometrial ISG17 mRNA and a related mRNA are induced by interferontau and localized to glandular epithelial and stromal cells from pregnant cows. Endocrine 10 243-252. (https://doi.org/10.1007/BF02738623)

Lima FS, Risco CA, Thatcher MJ, Benzaquen ME, Archbald LF, Santos JE \& Thatcher WW 2009 Comparison of reproductive performance in lactating dairy cows bred by natural service or timed artificial insemination. Journal of Dairy Science 92 5456-5466. (https://doi. org/10.3168/jds.2009-2197)

Louis GM, Cooney MA, Lynch CD \& Handal A 2008 Periconception window: advising the pregnancy-planning couple. Fertility and Sterility 89 e119-e121. (https://doi.org/10.1016/j.fertnstert.2007.12.043)

Matousek J, Soucek J, Slavik T, Tomanek M, Lee JE \& Raines RT 2003 Comprehensive comparison of the cytotoxic activities of Onconase and 
bovine seminal ribonuclease. Comparative Biochemistry and Physiology: Toxicology and Pharmacology 136 343-356. (https://doi.org/10.1016/j. cca.2003.10.005)

Mosmann T 1983 Rapid colorimetric assay for cellular growth and survival: application to proliferation and cytotoxicity assays. Journal of Immunological Methods 65 55-63. (https://doi.org/10.1016/00221759(83)90303-4)

Moura AA, Koc H, Chapman DA \& Killian GJ 2006 Identification of proteins in the accessory sex gland fluid associated with fertility indexes of dairy bulls: a proteomic approach. Journal of Andrology 27 201-211. (https://doi.org/10.2164/jandrol.05089)

Nocera M \& Chu TM 1995 Characterization of latent transforming growth factor-beta from human seminal plasma. American Journal of Reproductive Immunology 33 282-291. (https://doi.org/10.1111/j.1600-0897.1995. tb00897.x)

Nongbua T, Guo Y, Edman A, Humblot P \& Morrell JM 2018 Effect of bovine seminal plasma on bovine endometrial epithelial cells in culture. Reproduction in Domestic Animals = Zuchthygiene 53 85-92. (https:// doi.org/10.1111/rda.13069)

O WS, Chen HQ \& Chow PH 1988 Effects of male accessory sex gland secretions on early embryonic development in the golden hamster. Journal of Reproduction and Fertility 84 341-344. (https://doi. org/10.1530/jrf.0.0840341)

Odhiambo JF, Poole DH, Hughes L, Dejarnette JM, Inskeep EK \& Dailey RA 2009 Pregnancy outcome in dairy and beef cattle after artificial insemination and treatment with seminal plasma or transforming growth factor beta-1. Theriogenology 72 566-571. (https://doi.org/10.1016/j. theriogenology.2009.04.013)

O'Leary S, Robertson SA \& Armstrong DT 2002 The influence of seminal plasma on ovarian function in pigs-a novel inflammatory mechanism? Journal of Reproductive Immunology 57 225-238. (https://doi. org/10.1016/S0165-0378(02)00042-6)

O'Leary S, Jasper MJ, Warnes GM, Armstrong DT \& Robertson SA 2004 Seminal plasma regulates endometrial cytokine expression, leukocyte recruitment and embryo development in the pig. Reproduction 128 237-247. (https://doi.org/10.1530/rep.1.00160)

O'Leary S, Jasper MJ, Robertson SA \& Armstrong DT 2006 Seminal plasma regulates ovarian progesterone production, leukocyte recruitment and follicular cell responses in the pig. Reproduction 132 147-158. (https:// doi.org/10.1530/rep.1.01119)

O'Leary S, Armstrong DT \& Robertson SA 2011 Transforming growth factor-beta (TGFbeta) in porcine seminal plasma. Reproduction, Fertility, and Development 23 748-758. (https://doi.org/10.1071/RD11001)

Ortiz WG, Rizo JA, Carvalheira LR, Ahmed BMS, Estrada-Cortes E, Harstine BR, Bromfield JJ \& Hansen PJ 2019 Effects of intrauterine infusion of seminal plasma at artificial insemination on fertility of lactating Holstein cows. Journal of Dairy Science 102 6587-6594. (https://doi.org/10.3168/jds.2019-16251)

Pellegrino CA, Morotti F, Untura RM, Pontes JH, Pellegrino MF, Campolina JP, Seneda MM, Barbosa FA \& Henry M 2016 Use of sexed sorted semen for fixed-time artificial insemination or fixed-time embryo transfer of in vitro-produced embryos in cattle. Theriogenology $\mathbf{8 6} 888$ 893. (https://doi.org/10.1016/j.theriogenology.2016.03.010)

Robertson SA 2005 Seminal plasma and male factor signalling in the female reproductive tract. Cell and Tissue Research 322 43-52. (https:// doi.org/10.1007/s00441-005-1127-3)

Robertson SA \& Seamark RF 1990 Granulocyte macrophage colony stimulating factor (GM-CSF) in the murine reproductive tract: stimulation by seminal factors. Reproduction, Fertility, and Development 2 359-368. (https://doi.org/10.1071/rd9900359)

Robertson SA \& Seamark RF 1992 Granulocyte-macrophage colony stimulating factor (GM-CSF): one of a family of epithelial cell-derived cytokines in the preimplantation uterus. Reproduction, Fertility, and Development 4 435-448. (https://doi.org/10.1071/rd9920435)

Robertson SA, Mau VJ, Hudson SN \& Tremellen KP 1997 Cytokineleukocyte networks and the establishment of pregnancy. American Journal of Reproductive Immunology 37 438-442. (https://doi. org/10.1111/j.1600-0897.1997.tb00257.x)

Robertson SA, Ingman WV, O'Leary S, Sharkey DJ \& Tremellen KP 2002 Transforming growth factor beta - a mediator of immune deviation in seminal plasma. Journal of Reproductive Immunology 57 109-128. (https://doi.org/10.1016/S0165-0378(02)00015-3)
Robertson SA, Chin PY, Schjenken JE \& Thompson JG 2015 Female tract cytokines and developmental programming in embryos. Advances in Experimental Medicine and Biology 843 173-213. (https://doi. org/10.1007/978-1-4939-2480-6_7)

Saccone G, Di Spiezio Sardo A, Ciardulli A, Caissutti C, Spinelli M, Surbek D \& Von Wolff M 2019 Effectiveness of seminal plasma in in vitro fertilisation treatment: a systematic review and meta-analysis. BJOG 126 220-225. (https://doi.org/10.1111/1471-0528.15004)

Santos JE, Thatcher WW, Chebel RC, Cerri RL \& Galvao KN 2004 The effect of embryonic death rates in cattle on the efficacy of estrus synchronization programs. Animal Reproduction Science 82-83 513535, 513-535. (https://doi.org/10.1016/j.anireprosci.2004.04.015)

Sharkey DJ, Macpherson AM, Tremellen KP \& Robertson SA 2007 Seminal plasma differentially regulates inflammatory cytokine gene expression in human cervical and vaginal epithelial cells. Molecular Human Reproduction 13 491-501. (https://doi.org/10.1093/molehr/gam028)

Sharkey DJ, Macpherson AM, Tremellen KP, Mottershead DG, Gilchrist RB \& Robertson SA 2012a TGF-beta mediates proinflammatory seminal fluid signaling in human cervical epithelial cells. Journal of Immunology 189 1024-1035. (https://doi.org/10.4049/jimmunol.1200005)

Sharkey DJ, Tremellen KP, Jasper MJ, Gemzell-Danielsson K \& Robertson SA $2012 b$ Seminal fluid induces leukocyte recruitment and cytokine and chemokine mRNA expression in the human cervix after coitus. Journal of Immunology 188 2445-2454. (https://doi.org/10.4049/ jimmunol.1102736)

Tamburrini M, Scala G, Verde C, Ruocco MR, Parente A, Venuta S \& D'alessio G 1990 Immunosuppressive activity of bovine seminal RNase on T-cell proliferation. European Journal of Biochemistry 190 145-148. (https://doi.org/10.1111/j.1432-1033.1990.tb15557.x)

Tremellen KP, Seamark RF \& Robertson SA 1998 Seminal transforming growth factor beta1 stimulates granulocyte-macrophage colonystimulating factor production and inflammatory cell recruitment in the murine uterus. Biology of Reproduction 58 1217-1225. (https://doi. org/10.1095/biolreprod58.5.1217)

Tremellen KP, Valbuena D, Landeras J, Ballesteros A, Martinez J, Mendoza S, Norman RJ, Robertson SA \& Simon C 2000 The effect of intercourse on pregnancy rates during assisted human reproduction. Human Reproduction 15 2653-2658. (https://doi.org/10.1093/humrep/15.12.2653)

Tribulo P, Siqueira LGB, Oliveira LJ, Scheffler T \& Hansen PJ 2018 Identification of potential embryokines in the bovine reproductive tract. Journal of Dairy Science 101 690-704. (https://doi.org/10.3168/ jds.2017-13221)

Troedsson MH, Loset K, Alghamdi AM, Dahms B \& Crabo BG 2001 Interaction between equine semen and the endometrium: the inflammatory response to semen. Animal Reproduction Science $68273-$ 278. (https://doi.org/10.1016/S0378-4320(01)00164-6)

Viola M, Libra M, Callari D, Sinatra F, Spada D, Noto D, Emmanuele G, Romano F, Averna M, Pezzino FM et al. 2005 Bovine seminal ribonuclease is cytotoxic for both malignant and normal telomerasepositive cells. International Journal of Oncology 27 1071-1077. (https:// doi.org/10.3892/ijo.27.4.1071)

Wiltbank MC, Baez GM, Garcia-Guerra A, Toledo MZ, Monteiro PL, Melo LF, Ochoa JC, Santos JE \& Sartori R 2016 Pivotal periods for pregnancy loss during the first trimester of gestation in lactating dairy cows. Theriogenology 86 239-253. (https://doi.org/10.1016/j. theriogenology.2016.04.037)

Wooldridge LK \& Ealy AD 2019 Interleukin-6 increases inner cell mass numbers in bovine embryos. BMC Developmental Biology 19 2. (https:// doi.org/10.1186/s12861-019-0182-z)

Yanagimachi R \& Chang MC 1963 Infiltration of leucocytes into the uterine lumen of the golden hamster during the oestrous cycle and following mating. Journal of Reproduction and Fertility 5 389-396. (https://doi. org/10.1530/jrf.0.0050389)

Received 5 September 2019

First decision 17 October 2019

Revised manuscript received 18 October 2019

Accepted 22 October 2019 